Papers and Proceedings of the Royal Society of Tasmania, Volume 107

$$
\text { (ms. received } 9.10 .72)
$$

\title{
THREE NEW MICROPHALLID TREMATODES FROM TASMANIAN BIRDS
}

\author{
by S.J. Smith \\ Department of Zoology, University of Tasmania.
}

(with seven text-figures)

\section{ABSTRACT}

The morphology of Atriophazzophoms coxiezzae n.sp., Mamitrema calvertensis n.sp., and Microphallus tasmaniae n.sp. (Trematoda: Microphallidae) is described. The description of $A$, coxiellae is based on metacercariae found encysted in the hepatopancreas and gonads of the brackish water snail Coxielza badgerensis Johnston 1878. Adult, but sexually immature, trematodes taken from the small intestine of the dotterels Charadrius cuculzatus Vieillot and Charadrius ruficapizzus Temminck, which feed on Coxiella badgerensis, are considered identical with the metacercariae from the snail. The account of Maritrema calvertensis n.sp. is based on adult trematodes found in the lower intestine, caeca, and rectum of the duck, Anas castanea Eyton, and dotterels Charadrius cuculzatus and C. metanops Vieillot. From a comparison of metacercariae taken from certain small cysts found in the amphipod Austrochiztonia custralis Sayce 1901, and also in the alimentary tract of the birds, it is assumed that the amphipod is an intermediate host. The description of Microphallus tasmaniare n.sp. is based on adult trematodes found in the intestine, caeca and rectum of Anas castonea and the dotterels Charadrius cucullatus, C. melonops and C. muficapizlus. Certain large cysts found in the amphipod Austrochittonia australis, and also in the gut of the birds infected with Microphalius tasmaniae n.sp., contained metacercariae almost identical with the adult. It is therefore assumed that the amphipod is an intermediate host of $M$. tasmoniae n.sp. The definitive and intermediate hosts of the trematodes described were all taken at Calverts Lagoon, Tasmania.

\section{INTRODUCTION}

Yasin, (1967), in an account of the ecology of Calverts Lagoon, a permanent brackish water pond situated about $35 \mathrm{~km}$ south east of Hobart, Tasmania, reported the occurrence of larval digenetic trematodes in the snail Coxiezla badgerensis. $C$. badgerensis is the only mollusc known to inhabit the lagoon, and therefore all the digenetic trematodes which complete their life cycles at the lagoon must pass through their early larval development in this snail.

An investigation of the trematodes of the fauna of the lagoon has revealed the presence of three new species of microphallids. The description of the three species forms the subject of this paper.

Only one microphallid trematode has previously been described from Tasmanian fauna, that being Maritrema omithorhynchi Hickman 1955, which was found in the intestine of the platypus Omithorhynchus anatinus Shaw. Many microphallid species have been recorded from fauna, mainly charadrifform and anatiform birds, on the Australian mainland, (Johnston 1916; Deblock and Pearson 1968, 1969).

\section{MATERIALS AND METHODS}

One Anas castanea, three Charadrius cucullatus, two $C$. melanops, and one $C$. ruficopizzus inhabiting Calverts Lagoon were shot, taken to the laboratory and examined for adult trematodes. Hundreds of specimens of the snail, Coxielza badgerensis, 
and the anphipod Austrochiztonia austrazis were collected from the lagoon and exanined for trematode larval stages. Three types of metacercariae were found; one encysted in the snal and two encysted in the amphipod. The two types occurring in the amphipod were easily distinguished by a difference in size, one being twice the diameter of the other. To facilitate the examination of the metacercariae, the larvae were excysted. Excystment of those from the snail, and the larger of the two types from the amphipod was accomplished using a similar method to that described by Dixon (1966). After inmersion in $0.3 \%$ pancreatin solution for 30 minutes the cysts were incubated in Hank"s saline. Excystment of the sinaller cysts from the amphipod was effected nore successfully by immersion in sheep's bile, instead of the pancreatin solution. All media used for excystment were maintained at about $39^{\circ} \mathrm{C}$. Metacercariae with thick cyst walls and accumulations of excretory granules in their excretory vesicles were found to excyst more readily than those with thin cyst walls and no excretory granules. Unsuccessful attempts were made to infect chickens and rats with the three types of metacercariae (Smith 1971). Metacercariae from the snail were found to excyst within chickens, however they were voided within a few hours.

Sone live adult flukes removed from the intestines of wild birds, and sone of the excysted metacercariae, were drawn and photographed prior to fixation. The vital stains neutral red and brilliant cresyl blue were sometimes used to aid the morpho$\operatorname{logical}$ studies. Observations of flame cells and excretory ducts were facilitated by mounting the live specimens in tap water, or Hank's saline, under a coverslip, and then allowing the slide to dry slowly.

Fixation was accomplished using either T.C.A. modified Bouin's fixative, (T.C.A. replacing acetic acid), or $10 \%$ formal saline, after Dixon (1965). The trematodes were placed on a slide under slight coverslip pressure, relaxed in gentle heat, and then suddenly killed in hot fixative (Dawes 1946; Heard 1968). The flukes were stained whole in Horen's Trichrome (Horen 1957); Mallory's Heidenhain stain (Cason 1950); alum carmine; neutral red or toluidine blue. They were cleared in xylene, and mounted in either Canada Balsam, or D.P.X., via standard procedure.

In the following description all measurements were made on fixed material and are expressed in millimetres: the size range first, followed by the average in parenthesis.

$\begin{array}{lll}\text { Subfamily } & \text { MICROPHALLINAE } & \text { Ward } 1901 \\ \text { Genus } & \text { ATRIOPHALLOPIORUS } & \text { Deblock and Rose } 1964 \\ & \text { Atmiophazzophoms coxieztae n.sp. }\end{array}$

The following description is based on more than 50 well developed metacercariae, excysted experimentally, after removal from the snail Coxiezza badgerensis. Motile spermatozoa were present in the seminal vesicles of some of the flukes.

Description (fig. 1)

Dimiensions: Body length, 0.143-0.229 (0.195); maximum body width, 0.072-0.125 $(0.090)$; oral sucker, 0.026-0.034 (0.029); ventral sucker, 0.026-0.031 (0.029); pharynx, $0.016-0.044(0.020) \times 0.015-0.020(0.017)$; testes, $0.036-0.040(0.039)$ maximum width; seminal vesicle, 0.029-0.036 (0.034) maximun width; ovary, 0.030-0.048 (0.035) maximum width; ootype, $0.018 \times 0.013$.

The body is pyriform to triangular; curved concave ventrally, particularly in the posterior region. The living fluke supports itself on the substratum by the oral sucker, and two posterior ambulatory buds. The outer tegument bears spines over the whole body, which are more prominent anteriorly. The spines are comb-like structures, triangular in lateral view. The round, subterminal, oral sucker is approximately equal in size to the ventral sucker; the latter is situated about two-thirds of the body length from the anterior end. The pharynx is spatulate; prepharynx is very short or absent, depending on the degree of contraction. The oesophagus varies in length as the fluke moves. The caeca may be slender or saccate; diverging widely and extending 
KEY TO SYMBOLS

c caecum; cs cirrus sac; e egg; ed excretory duct; eg excretory granules; ev excretory vesicle; fc flame cel1; ga genital atrium; gp genital pore; o ovary; oe oesophagus; oo ootype; os oral sucker; ph pharynx; pp phallophore; pph prepharynx; ps pars prostatica; sv seminal vesicle; t testis; ts tegumental spines; $v$ vite $\bar{l}$ laria; vs ventral sucker.

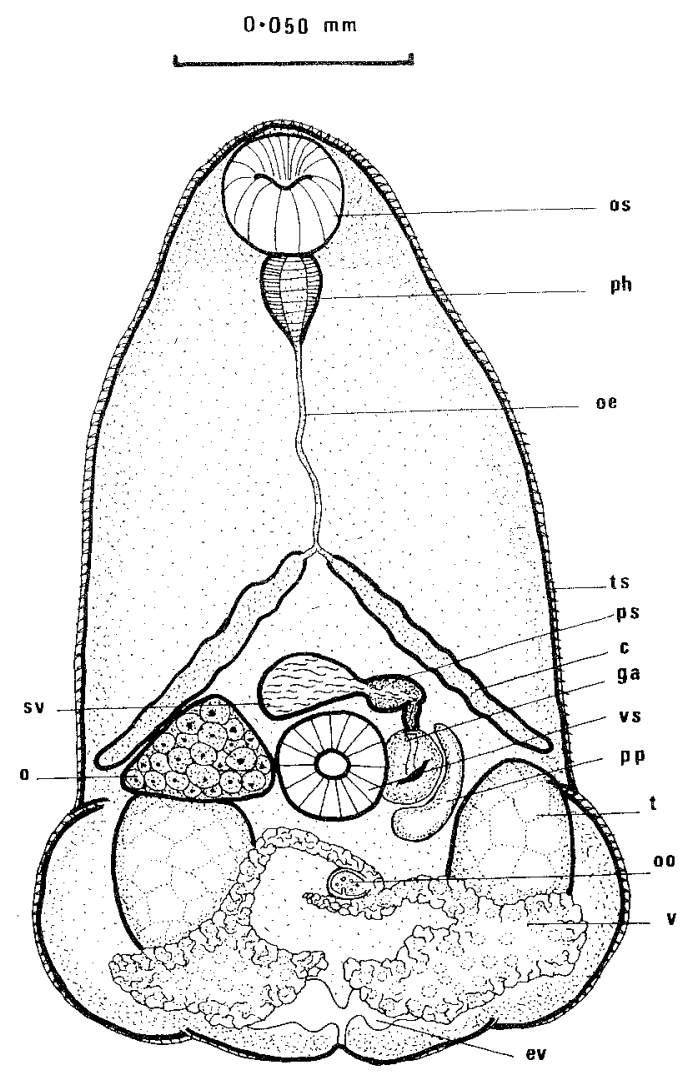

FIG. 1. - Atriophalzophorus coxiezzae n.sp., excysted metacercaria, showing reproductive and digestive systems, ventral view.

to the level of the ventral sucker.

The oval testes are lateral, slightly diagonal, in the posteroacetabular region. The seminal vesicle, between the caecal arch and ventral sucker, is oval to reniform. Extending from right to left, it leads via a well-developed pars prostatica, and sinuous ejaculatory duct, to the male papilla, which is contained within a simple, round, sinistral genital atrium. A large semi-lunar, muscular chamber lies in juxtaposition to the left of the genital atrium. The dextral ovary is oval to triangular; located at the acetabular level, between the testes and caecum of the right side. A thick walled, oval, ootype is situated posteromedially, at the level of the testes. Vitellaria are in two symmetrical groups, posterior to, or overlapping the testes; vitelline ducts converge anteriorly, meeting next to the ootype. The receptaculum seminis, Laurer's canal and uterus were not seen.

The excretory system is shown in figure 2. Excretory ducts in the posterior region are obscured by reproductive structures, however the distribution of flamecells is typical of the family (Stunkard 1958; James 1968); the flame-cell formula is $2((2+2)+(2+2))=16$. Dark brown granules fill the V-shaped excretory vesicle in older metacercariae.

The incidence of $A$. coxiezzae n.sp. in Coxiezza badgerensis varies seasonally. However, from 1035 snails examined between February and october 1970, 17.2\% were infected with cysts of this microphallid species. The cyst diameter increases from 


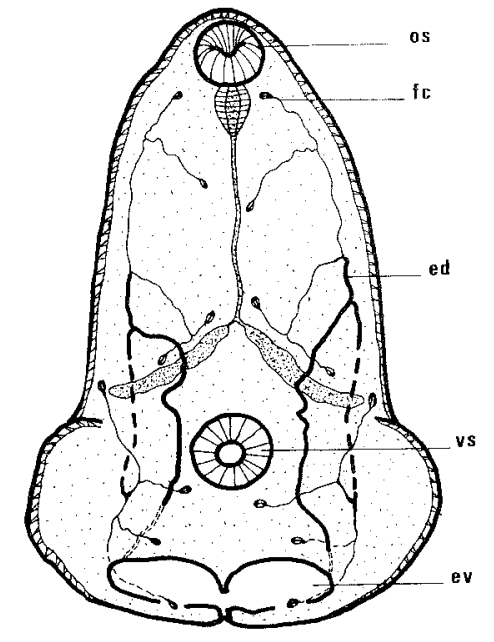

FIG. 2. - Atriophazlophorus coxielzae n.sp., excysted metacercaria, showing excretory system, ventral view.
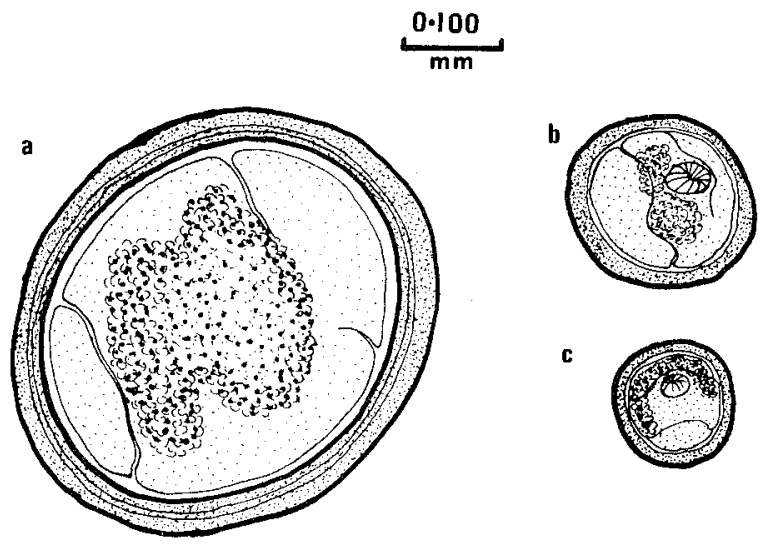

c

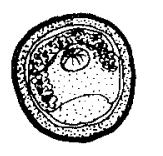

$0.088 \mathrm{~mm}$, newly formed, to $0.125 \mathrm{~mm}$, in older cysts, (fig. 3). One of 3 specimens of the dotterel Charadrius cuculzatus examined was infected with $A$. coxiezlae n.sp. The only specimen of Charadrius micapilzus examined was heavily infected with $A$. coxiezzae n.sp. Specimens of $A$. coxiezzae n. sp. obtained from the birds were identical in size and morphology to the excysted metacercariae from the snail-however they were not gravid, and details of the reproductive system were not clearly seen. Cysts, identical in size to those from the snail, and fragments of the snail were found in all of the infected birds.

Probable definitive hosts:

Charadrius cucullatus Vieillot, C. muficapizlus Temminck.

Habitat: small intestine and rectum.

$\frac{\text { Intemediate Host: Coxiezza badgerensis }}{\text { Johnston. }}$

Habitat: hepatopancreas and gonads.

Geographical Location: Calverts Lagoon (Tasmania).

Type Material: Tasmanian Museum - holotype K246; Paratypes K245, K247, K248.

\section{DISCUSSION}

No microphallids have previously been recorded from either of the two Charadrius species, C. cuculitatus and $C$. ruficapizzus.

A. coxiezzae n.sp. is very similar to the diminutive microphallid A. minutus (Price 1934) Deblock and Rose 1964 in morphology. and life history. Both species have reduced life cycles, cysts being formed within the molluscan host, however A. minutus develops in the freshwater snails Hydrobia minuta and Amnicola Zimosa, and infect the duck Nyroca affinis (Stunkard 1958). A. coxiezzae has a large clavate, muscular chamber adjacent to the genital atrium.

FIG. 3. - Cysts of (a) Microphazzus tasmaniae n.sp.;This structure appears to be (b) Maritrema calvertensis n.sp.; and (c) Atriophallophorus coxielzae n.sp., drawn to scale. analogous to the phallophore, an hemispherical, muscular, periatrial envelope which is characteristic of

AtriophazZophoms Deblock and Rose 1964. 
The new species, A. coxielzae n.sp., is named after the snail, Coxiezla badgerensis, which serves as host for its larval stages.

$\begin{array}{llcl}\text { Subfamily } & \text { MARITREMATINAE } & \text { Belopolskaia } & 1952 \\ \text { Genus } & \text { MARITREMA } & \text { Nicol1 } & 1907 \\ & \text { Maritrema calvertensis n.sp. } & \end{array}$

The following description is based on about 50 ovigerous specimens obtained from the duck Anas castonea and dotterels Charadmius cuculzatus and C. meZonops. Apart from differences in size, no marked variations are apparent in specimens either from the one, or from all three hosts.

Description (fig. 4)

Dimensions: body length, 0.191-0.268 (0.215); maximum body width, 0.124-0.187 (0.144); oral sucker, 0.023-0.034 (0.029); ventral sucker, 0.027-0.031 (0.029); pharynx, 0.018-0.022(0.020) long and wide; testes, 0.036-0.047 (0.040) maximum width; ovary, $0.025-0.030(0.027)$ maximum width; eggs $(0.018-0.023(0.021) \times 0.010-0.015$ $(0.012)$.

The body is ovoid to pyriform; maximum width occurring at the level of the anterior of the testes. The outer tegument is uniformly covered by minute, comb-shaped spines. The subterminal oral sucker, and medial ventral sucker are approximately equal in size. The prepharynx is short or absent depending on the state of contraction; pharynx is barrelshaped. The short oesophagus bifurcates to form obtusely diverging caeca, which extend two-thirds of the way to the lateral body wall.

The ovoid testes are opposite, posterolateral to the ventral sucker. A well-developed cirrus-sac extends from left to right, almost the body width, between the caecal arch and ventral sucker. Within the cirrus-sac is the clavate, seminal vesicle, tapering towards the pars prostatica. The distal end of the cirrus sac is hooked; ejaculatory duct curving posteromedially to the male papilla, and simple, sinistral, genital atrium.

The dextral, ovoid ovary, is situated between the right testes and the proximal end of the cirrus-sac. Vitellaria encircle the testiculo-uterine region in a dense, chainlike formation. Four to ten, non-operculate eggs are contained in the uterus at a time; the latter not passing forward of the ventral

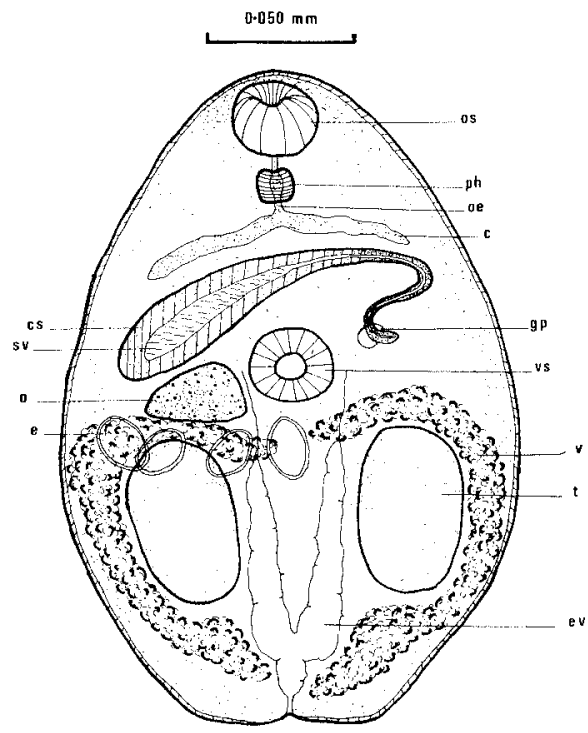

FIG. 4. - Maritrema calvertensis n.sp., adult, showing digestive and reproductive systems, and distribution of eggs, ventral view. sucker.

The arms of the $\mathrm{Y}$-shaped excretory vesicle extend forward to the anterior margin of the testes. The stem and arms may be dilated or contracted in living specimens. No flame cells were observed.

One specimen of Anas castonea, three specimens of Charadrius cucultatus, and one specimen. of $C$. me zonops were examined and all were infected with $M$. calvertensis n.sp. Apart from differences in size and sexual maturity, metacercariae excysted from the smaller type of trematode cyst present in the amphipod Austrochiltonia australis, (about $0.170 \mathrm{~mm}$ diameter), were identical to Maritrema calvertensis n.sp. (figs. 3, 5). 
Similarly sized cysts, along with the remains of $A$. australis, were found in the alimentary tracts of birds infected with $M$. calvertensis n.sp. It is reasonable to assume that the metacercaria in the amphipod is a stage in the life-cycle of this tremat ode. The incidence of small cysts in $A$. custralis is very high (about $90 \%$ ) throughout the year.

Definitive hosts: Anas castonea Eyton, Charadmius cucullatus Vieillot, and $C$. melanops vieillot.

Habitat: $\quad$ Lower intestine, caeca and rectum.

Probable Intermediate Hosts: Coxiezza badgerensis Johnston and Austrochiztonia australis Sayce.

Habitat: Hepatopancreas and haemocoel respectively.

Geographical Location: Calverts Lagoon (Tasmania).

Type Material: $\quad$ Tasmanian Museum - holotype K250 (ringed and arrowed); paratypes $\mathrm{k} 250$ (ringed but no arrow). K249 (ringed on slide), K251 (ringed on s1ide), K252 (metacercaria).

Discussion

M. calvertensis n.sp. is similar to M. oocysta (Lebour) (syn. M. humi.le Nicoll and $M$. imae Leonov) and $M$. sobolevi Kurotsckin, which may be synonyms of the same species (Deblock and Combes 1965). M. calvertensis differs from these species in having a smaller body, and a much shorter prepharynx, which is equal in length to the oesophagus. It also has a markedly different life cycle. $M$. oocysta encysts in the molluscan host, and lives in charadriiform birds in Western Europe, and lariform birds in Eastern Europe (Reimer 1963; Deblock and Combes 1965); $M$. sobozevi encysts in an amphipod, and lives in seals in the Caspian sea (Deblock and Combes 1965); and M. calvertensis n.sp. develops in the brackish water snail Coxielza badgerensis, encysts in the amphipod Austrochiztonia australis, and reaches sexual maturity in nonmigratory Tasmanian dotterels and ducks.

The new species is named after the lagoon in which the definitive and intermediate hosts were found.

$\begin{array}{lll}\text { Subfami1y } & \text { MICROPHALLINAE } & \text { Ward } 1901 \\ \text { Genus } & \text { MICROPHALLUS } & \text { Ward } 1901 \\ \text { Subgenus } & \text { MICROPHALLUS } & \text { Deblock and Pearson } 1969 \\ & \text { Microphazlus tasmaniae n.sp. }\end{array}$

The following description is based on more than 50 ovigerous specimens obtained from the duck Anas castanea, and dotterels Charadrius cuculzatus, C. mezonops and C. mficapizzus. Apart from differences in size, no marked variations are apparent in specimens either from the one, or from all four hosts.

Description (fig. 6)

Dimensions: body length, $0.491-1.810$ (0.880); maximum body width, 0.220-0.364 $(0.307)$; oral sucker, $0.055-0.085(0.073)$; ventral sucker, 0.048-0.070 (0.062); pharynx, $0.020-0.052(0.042) \times 0.023-0.034(0.029) ; \quad$ testes, $0.072-0.098(0.078)$ maximum width; genital atrium, 0.030.0.039 (0.036); ovary, 0.040-0.078 (0.070) maxi mum width; eggs, $0.021-0.025(0.023) \times 0.012-0.019(0.016)$.

The body is elongate pyriform; maximun width occurring at the level of the testes. The anterior two-thirds is covered with transverse rows of spines, which diminish in size posteriorly. The ventral sucker is usually slightly smaller than the oral sucker. The prepharynx is long; barrel-shaped pharynx situated mediad; oesophagus varying in length as the fluke moves. Two saccular caeca diverge acutely, extending to the level of the anterior border of the ventral sucker. 
The testes are ovoid, opposite, situated posterolaterally to the ventral sucker. The transverse, oval to reniform seminal vesicle, between the caecal arch and ventral sucker, is connected by a well-developed pars prostatica, and ejaculatory duct to the male papilla in a simple, round, sinistral, genital atrium. The ovary is oval to triangular, between the testes and caecum of the right side. The vitellaria consist of numerous follicles, grouped posterior to, or overlapping, the testes. The uterus, entirely post-acetabular, passes backwards forming a series of loops over the right testis, crossing and looping over the left testis, before entering the sinistral, genital atrium. The oval, non-operculate eggs, numbering 35 to 100 within the uterus, are not embryonated on deposition.

No flame cells were observed.

One specimen of Anias castanea, three specimens of Charadrius cuculzatus, one specimen of C. melanops, and one specimen of $C$. ruficapizlus were infected with Microphallus tasmaniae n.sp. Metacercariae excysted from the larger type of trematode cyst (about $0.437 \mathrm{~mm}$ in diameter) present in the amphipod Austrochiztonia australis, were found to be almost identical with Microphallus tasmaniae n.sp. differing only slightly in size and sexual maturity (figs. 3, 7). Similarly sized cysts, along with the remains of the amphipod, were present in the digestive tracts of the birds infected with $M$. tasmaniae n.sp. It is assumed therefore that the metacercariae of these cysts represent a larval stage of $M$. tasmoniae $\mathrm{n}$. sp. The incidence of these large cysts in $A$. australis is about $90 \%$, throughout the year.

Definitive Hosts: Anas castonea Eyton, Charadrius cuculzatus Vieillot, C. melanops Vieillot, and C. mificopizlus Temminck.

Habitat: Mainly caecum; also intestine and rectum.

Probable Intermediate Hosts: Coxiezza badgerensis Johnston, Austrochiztonia australis sayce.

Habitat: Hepatopancreas and haemocoel respectively.

Geographical Location: Calverts Lagoon, (Tasmania).

Type Material: Tasmanian Museum - holotype K254 (ringed); paratypes K254 (not ringed), K253, K255, K256, K257 (metacercaria), K258 (metacercariae).

Discussion

Five species of the genus Microphallus have previously been described from Australian fauna. (Deblock and Pearson 1969). Three of these species were found infecting

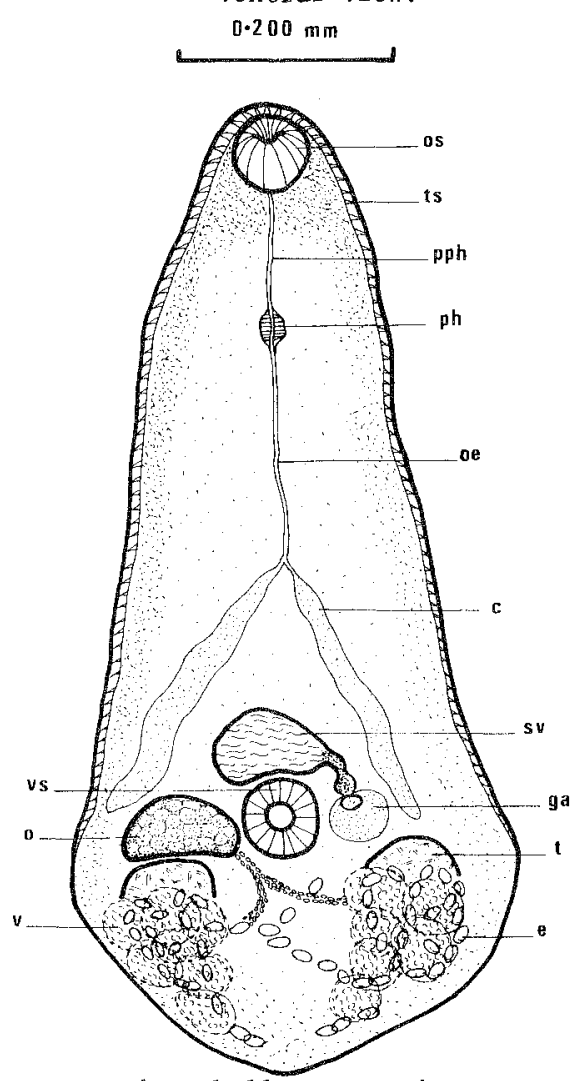

FIG. 6.- Microphazlus tasmakiae n.sp., adult, showing general organization, and distribution of eggs, ventral view. 
the dot terels, Charadrius dominious Mull and C. mongolus Pallas, in Queensland.

M. tamoniae n.sp. is similar to M. papizZorobustus (Rankin 1940) (syn. M. chab-

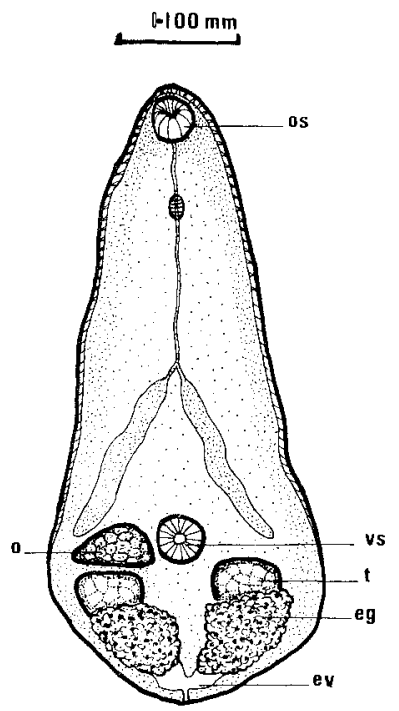

FIG. 7.- Microphazlus tasmaniae n.sp., excysted metacercaria, ventral view.

audi, M. magnipapillata) Deblock and Pearson 1969; and in both species an amphipod serves as an intermediate host (Belopolskaia 1952). M. papizZorobustus encysts in Gammarus locusta, and infects charadriiform and 1ariform birds of the old and new worlds; and $M$. tasmaniae n.sp. encysts in Austrochiztonia australis, and infects non-migratory Tasmanian dotterels and ducks. M. tasmaniae n.sp. differs from $M$. papizzorobustus in having a smaller, less conspicuous male papil1a, longer body, and larger ventral sucker.

The name Microphallus tasmaniae n.sp. is proposed because this is the first species of Microphalzus to be described from Tasmania.

\section{ACKNOWLEDGEMENTS}

I an very grateful to Dr. J.L. Hickman for his advice and encouragement during the course of this study, and in the preparation of this paper. I am also indebted to the others on the staff of the Zoology Department, University of Tasmania, who have assisted me in various ways. My thanks are also due to Mr. K. Calvert, and The Animals and Birds Protection Board of Tasmania, from whom permission was obtained to collect fauna from Calverts Lagoon.

\section{REFERENCES}

Belopolskaia, M.M., 1952: La famille des Microphallidae Travassos, 1920. in Trématodes des animaux et de l'homme, 1952, VI, 619-756, de K.I. Srkiabine.

Cason, J.E., 1950: A rapid one-step Mallory Heidenhain for connective tissue. Stain Technology, 25, 4, 225-226.

Dawes, B., 1946: The Trematoda. Cambridge University Press.

Deblock, S, and Combes, C., 1965: Contribution a l'étude des Microphallidae, Travassos 1920 (Trematoda). X - Maritrema pyrenaica n.sp. Essai de cle diagnostique des éspeces du genre. BulZ. Soc. Zool. France, XC, 1, 101-117.

, and Pearson, J.C., 1968: Contribution a L'étude des Microphallidae Travassos, 1920 (Trematoda), XV. Ann. Par. Hzm. Comp., XLIII, 4, 457-465.

, and Pearson, J.C., 1969: Contribution a l'étude des Microphazlidae Travassos, 1920 (Trematoda). XVIII - Essai de clé diagnostiques des éspeces du genre Microphazlus. Ann. Por. Hom. Comp., XLIV, 4, 391-414.

, and Rose, F., 1964a: Contribution a l'étude des Microphalzidae Travassos, 1920 (Trematode) des oiseaux de France. VIII - Creation du genre Atriophallophorus, parasite de canards sauvages. Bull. Soc. Zool. France, 2-3, LXXXIX, 225-232.

, and Rose, F., 1964b: Contribution a L'étude des Microphallidae Travassos, 1920 (Trematoda) des oiseaux de France. IX. BuZZ. Soc. Zool. France, LXXXIX, 4, 429-443. 
Dixon, K.E., 1965: The structure and histochemistry of the cyst wall of the metacercaria of Fasciola hepatica L. Parasitology, 55, 2, 215-226.

, 1966: The physiology of excystment of the metacercaria of Fasciola hepatica L. Parasitozogy, 56, 3, 431-456.

Heard, R.W., 1968: Levinsenielza hunteri nov. sp., a new species of micropha1lid trematode from the Wilson's Plover, Charadrius wilsonia. Proc. Helm. Soc. Wash., $35,1,140-143$.

Hickman, V.V., 1955: On Mamitrema ornithorhynchi sp.n., with a key to the genus Maritrema Nicoll. Rev. Iberica Parasitol, Tomo Extraordinario, 181-191.

Horen, P., 1957: Research notes on a new stain. J. Earasit., 43, 6, 669.

James, B.L., 1968: Studies on the life cycle of MicrophaZZus pygmaeus (Trematoda: Micropha11idae). J. Nat. Hist., 2, 155-172.

Johnston, S.J., 1916: On the trematodes of Australian birds. J. Proc. Roy. Soc. N.S.W., $50,187-261$.

Reimer, L., 1963: Zur verbreitung der adulti und larvenstadien der familie Microphallidae Viana, 1924 (Trematoda, Digenea) in der Mittleren Ostsee. 2. f. Parasitenkunde, 23, 253-273.

Smith, S.J., 1971: A study of some larval digenetic trematodes infecting invertebrates in Calverts Lagoon; and descriptions of the microphallids: Microphalzus tasmoniae n.sp. Maritrema calvertensis n.sp. and Atriophalzophoms coxiezzae n. sp. Univ. Tasm. Dep. Zool. Thesis unpub.

Stunkard, H.W., 1958: The morphology and life history of Levinsenielza minuta. (Trematoda, Microphallidae). J. Parasit., 44, 225-230.

Yasin, M., 1967: The Ecology of a Temporary and a Permanent Pond in Tasmania. Univ. Tasm. Dep. Zool. Thesis unpub. 